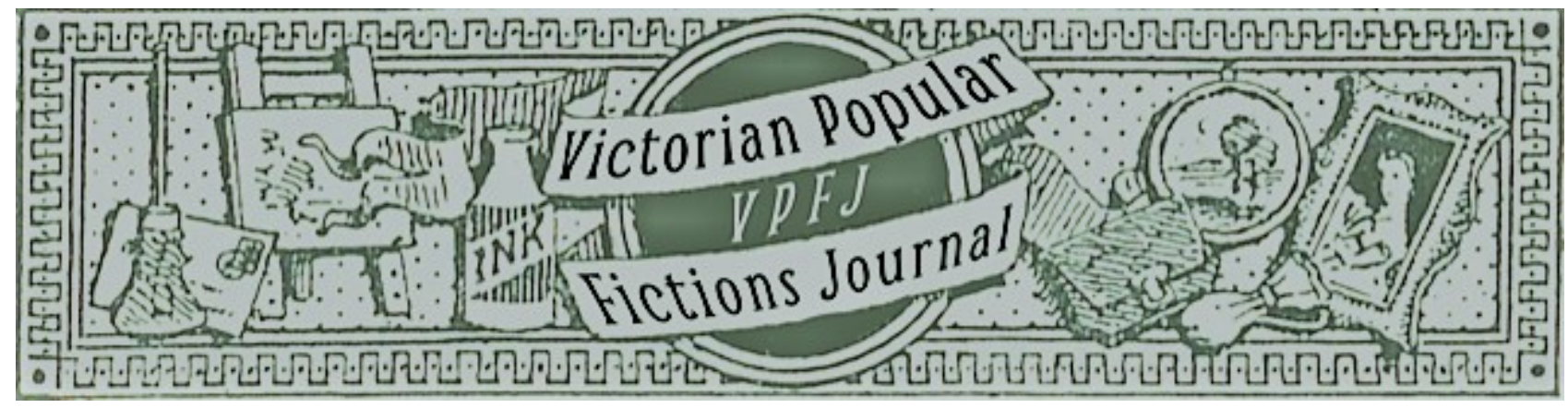

\title{
Exploring Late Victorian (Co-)Authorship: Two Models of Popular Literary Collaboration
}

\author{
Annachiara Cozzi
}

\begin{abstract}
The lively and competitive popular literary market of the late Victorian era provided fertile ground for the development of an unprecedented number of alliances between authors. Literary collaboration triggered writers and readers alike, and in the $1880 \mathrm{~s}$ and $1890 \mathrm{~s}$ it became a fashionable practice of popular literature. Two writing partnerships stood out: the English friends Walter Besant and James Rice, and the Anglo-Irish cousins Edith Somerville and Violet (Martin) Ross. Apparently similar, these partnerships do indeed share some points, but they were based on completely different understandings of what literary collaboration was and how it should be handled: Besant and Rice's alliance was based on a clear, almost mechanical division of tasks, with one partner being the literary 'genius' and the other working as his assistant and manager - but still to be considered an author; Somerville and Ross's collaboration was grounded on an intertwining of their selves during the creative process thanks to a conversational method - as they called it - which they described as the mixing of primary colours to create secondary ones. Drawing on a vast range of metadiscourses by these collaborators themselves, the present study compares the two ways of collaborating and reconstructs the authors' perspective on their own activity, shedding light on how literary collaboration was defined and understood in the late Victorian era. This will also help to understand why such a widespread practice swiftly declined and why its products have since then sunk into oblivion.
\end{abstract}

\section{Keywords}

Walter Besant; James Rice; Edith Enone Somerville; Martin Ross; literary collaboration; co-authorship; co-authored novels; popular collaborators; late Victorian popular literature.

Date of Acceptance: 5 July 2021

Date of Publication: 8 July 2021

Double Blind Peer Reviewed

\section{Recommended Citation:}

Cozzi, Annachiara. 2021. "Exploring Late Victorian (Co-)Authorship: Two Models of Popular Literary Collaboration." Victorian Popular Fictions 3.1 (Spring): 33-54. DOI: https://doi.org/ $\underline{10.46911 / \text { STUL5984 }}$ 




\title{
Exploring Late Victorian (Co-)Authorship: Two Models of Popular Literary Collaboration
}

\author{
Annachiara Cozzi
}

\section{Literary Alliances: A Fashionable Practice}

There will come a time when both men fret under the condition; when each desires, but is not able, to enjoy the reputation of his own good work; and feels, with the jealousy natural to an artist, irritated by the loss of half of himself and ready to accept the responsibility of failure in order to make sure of the meed of success.

(Besant 1902: 188)

Writing together is $[\ldots]$ one of the greatest pleasures I have. To write with you doubles the triumph and the enjoyment, having first halved the trouble and anxiety.

(Letter from Martin Ross to Edith Somerville, Sept. 1889, in Somerville and Ross 1917: 134)

Literary collaboration could not be described more differently. The peculiar practice of co-authorship in fiction-writing, indeed, has always been felt as controversial by readers and authors alike. ${ }^{1}$ The collaborative writer, who by definition 'works with' (cum/laborare > collaborat) someone else, destabilises the first notion of post-Romantic authorship: solitude. Within the collaborative dynamic, the writer "inevitably encounters a relational difficulty: acknowledging the other" (Karell 2008: 25). The collaborator shares the creative moment with someone: thus, the codified model of the literary text as the expression of an author's self is undermined. Collaboration implies losing one's God-like authority over the text; it involves deliberately suppressing one's ego. No longer a nightingale "who sings to cheer its own solitude" - to use Shelley's words (Shelley [1821] 1964: 172) - the collaborative author faces (or enjoys) totally different conditions from the solitary one.

\footnotetext{
${ }^{1}$ Within critical studies on collaboration, there is as yet confusion and disagreement on the proper parameters of the subject. I agree with Ede and Lunsford 1990, Koestenbaum 1989 and Laird 2000 in maintaining that 'collaboration' or 'co-authorship' refers to acts of writing in which two or more individuals intentionally work together at every stage to produce a common text and acknowledge it. I therefore exclude from my analysis broader interpretations of the term, such as acts of assistance and inspiration, mentoring, influence, revision, editorial alterations, ghost-writing, unfinished novels completed by someone else, and other forms of 'hidden' or unacknowledged collaboration. Mutual acknowledgment and intentionality are fundamental elements for the kind of collaboration this work deals with.
} 
Collaboration in novel-writing assumed the proportions of a literary fashion in the later part of the Victorian age, probably as the result of an increasingly composite and competitive literary market and of a lively literary atmosphere, open to experiments. As Ashton (2003: 8) maintains, despite earlier and more recent occurrences of collaborative fiction, "the propensity for writers of the late nineteenth century to write together was a distinct phenomenon." Authors experimented with innovative ways to cope with the fast and disconcerting market; by forming alliances, some managed to find their voice and to grow in confidence. Also, the periodical market was always hungry for novelties. Editors would set up collaborations for new serials, hoping to arouse the public's curiosity. Writing for the popular market, co-authors inserted themselves in the trendiest subgenres of the period: mainly sensation, adventure and fantasy novels, but also romances and sentimental novels. ${ }^{2}$

Literary collaboration and popular literature were therefore strictly interwoven. In the 1880s, and especially in the 1890s, virtually all popular novelists tried their hands at it at least once. Stevenson, Kipling, Conan Doyle, Stoker, Rider Haggard, Andrew Lang, and Rhoda Broughton just to mention some - all took part in more or less successful collaborative ventures. As collaborative writing gained popularity, the press started to pay more and more attention to it. The idea of a shared writing practice had become very popular and yet very difficult to explain; the fact was, collaboration eluded definite understanding: it was a "puzzle [...], an enigma [...], "a nut to crack" (Matthews [1890] 1891:1). The dispersion of author-ity implicit in collaboration triggered a lively debate in the press over the benefits and the limits of writing in double harness, as it was sometimes called.

Despite some remarkabe studies on literary collaboration over the last thirty years, collaborative texts have generally been ignored or pushed to the margins; authors of canonical prominence are so for their solo work, while the fiction they wrote collaboratively has been considered unimportant side-production. ${ }^{3}$ The vast majority of those late Victorians who practiced co-authorship - with rare exceptions like the aunt-and-niece writing couple "Michael Field"4 who most certainly did not participate in the popular - have plunged into darkness. The absence of co-authors from the canon has been ascribed by critics to the fact that co-authorship presents challenges to accepted notions of authorship. Sustained scholarship on collaboration started in the 1990s, and most critical investigations underlined that, ever since the Romantic period, the concept of the artist as a solitary genius - to borrow Stillinger's (1991) terminology - who creates original works of art in isolation has imposed itself as a fundamental feature of the artistic process, excluding any other understanding of authorship. Jamison (2016: 81) summarises that "[t]he sharing of textual spaces, and the dispersal of authorial ownership and control, defies literary models of authorship that favour Romantic ideals of the solitary author" (see also Ede and Lunsford 1990: 85; Boucharenc 2000: 100; Masten 1997: 16).

Although these discourses provide more than valuable starting points, they remain abstract considerations. Most studies do not examine what were the practical consequences of the Romantic conception of authorship for Victorian readers, editors, publishers, agents, and, most importantly, for co-authors. As the present study will show, prolific and successful Victorian co-authors displayed

\footnotetext{
${ }^{2}$ I have extensively dealt with the proliferation of co-authored novels in the late nineteenth century and I have carried out a survey of other popular literary partnerships in my PhD thesis (Cozzi 2020). See also Cozzi 2019.

${ }^{3}$ Critical studies have on the whole neglected authors' collaborative experiences, although some valuable work has been recently done on Stevenson (see Buckton 2007) and Lang (see Hensley 2013 \& 2015).

${ }^{4}$ The present study does not deal with the poets, dramatists and diarists Katherine Bradley and Edith Cooper, who wrote under the composite pseudonym "Michael Field," as their joint work cannot be defined popular. Michael Field has received critical attention since "his" lifetime, and is by far the best known late-Victorian literary collaboration. On Michael Field, see Marion Thain's seminal work Michael Field. Poetry, Aestheticism, and the Fin de Siècle (2007).
} 
a strong belief in the myth of the inspired solitary author and went so far as to deny collaborative texts - their texts - any serious artistic value. Inserting itself in the pressing debate within the field of Victorian authorship, this article argues that the exclusion of late Victorian collaborators from contemporary critical attention is not only simply ascribable to the unsettling implications of co-authorship itself; more concretely, such exclusion has its roots in their days, back in the nineteenth century, in the very context in which such collaborations developed, flourished and perished.

In order to understand how the debated practice of literary collaboration was seen between 1870 and the turn of the century, this study reconstructs and compares the perspectives of two of the most noteworthy writing couples of the time: that of Walter Besant and James Rice, and that of Edith Somerville and Violet (Martin) Ross. ${ }^{5}$ Both were exclusive, long-term literary relationships, interrupted only by the death of one member; in both cases, collaboration brought success to the previously unknown partners. Their popularity derived entirely from the partnership, and the double signatures they put on their works acquired brand-name recognition. However, these partnerships were based on completely different premises. They cultivated distinct understandings of what literary collaboration was and should be. As the present work will illustrate, their apparently analogous collaborations offer two divergent models of co-authorship. Drawing on a vast range of metadiscourses by these collaborators themselves - that is, the articles, essays, paratexts, private correspondence, and autobiographies in which they talked of their experience - it is possible to grasp how they perceived their own activity over time.

The two writing partnerships examined here have been chosen for the stark contrast between their fame during their lifetime and the subsequent oblivion they slipped into. Although very well known during their lives, nowadays we have but a faint idea of who Walter Besant (1836-1901) was, and even fewer of us have heard the name of James Rice (1843-1882). When their partnership began in 1871, co-authorship in novel writing was an eccentric practice rarely heard of; when Rice died in 1882, it had become the literary fashion of the time. When the collaboration with Rice was put an end to, Besant kept writing steadily on his own and never engaged in another long-term collaboration. Boege (1956a: 249) remarks that, when Besant declared that his name was "known all over the English-speaking world" (Besant 1902: 215), "he was stating an obvious truth that any of his readers would have assented to." He advocated for copyright, founded and directed the Society of Authors and was editor of its journal, The Author. He was the key figure in the building of the first institution aimed at offering education and recreation to the inhabitants of the London's East End, the People's Palace. ${ }^{6}$ In 1895 he was knighted by Queen Victoria. Doubtlessly, in the 1880s and 1890s he was "one of Britain's most lionized living novelists" (Morrison 2019: 1). Yet a few decades into the twentieth century he was forgotten, at best associated with his role in the Society of Authors or for his essay "The Art of Fiction," which led Henry James to write his much more renowned answer. Rice, on his part, sank into utter darkness. Besant and Rice find little or no place in the common reference works: at best, their names are mentioned and dismissed in a few lines or in a footnote. Some critical interest in Besant alone has been revived since the 1990s and especially in the last decade, ${ }^{7}$ yet so far there is no monograph on the partnership of Besant and Rice.

\footnotetext{
${ }^{5}$ The popular and critical acclaim of Besant and Rice and Somerville and Ross is attested to by the periodical press of the time. I have delved into the discourse that developed in the British press about literary collaboration from the second half of the nineteenth century to 1900, and the names of Besant and Rice and Somerville and Ross are the most discussed ones. My research has drawn mainly on two resources: the British Newspaper Archive online and the archives of the British Library in London. For an in-depth discussion of how literary collaboration was represented and valued in the nineteenth-century periodical press, see Cozzi 2019.

${ }^{6}$ On Besant's role in the People's Palace, see Weiner 1994 and Joyce 1996.

${ }^{7}$ The main studies on Besant before 1990 are Boege (1956a \& 1956b), Keating 1973 and Eliot (1987 \& 1989). From the 1990s, see, among others: Neetens 1990, Colby 1990, Eliot 1999, Reid 2001, DeVine 2002, Faulk 2004, Bivona and Henkle 2006, Swafford 2007, Banerjee 2014, Gannon 2014, Ghosh 2017, and Ginn 2017.
} 
Things have gone slightly better for the Anglo-Irish feminists Somerville and Ross. Between 1888 and 1915, Edith Enone Somerville (1858-1949) and Violet Florence Martin (1862-1915) jointly published five novels, various collections of short stories, four travel accounts, and a variety of periodical literature. At the turn of the century and in the first decades of the twentieth century the duo's fame was enormous, so much so that their texts were distributed to soldiers in the First World War to cheer them up. When Martin died, Somerville survived her by thirty-four years but never wrote with anyone else; drawing on ideas she had discussed with Martin, she went on writing on her own until her death. Even if their popularity has since then decreased significantly, they have never completely dropped out of the canon of Irish literature (London 1999: 5). They have often been compared to Maria Edgeworth because of the similarities in both their background (they were born and spent most of their lives in Ascendancy Big Houses) and their work, such as the use of Hiberno- English and their ironical representation of the decline of the Ascendancy (Kreilkamp 2006: 60-77, Kreilkamp 2010: 50-65). They have been acknowledged by feminist criticism as key figures for the study of women's literary partnerships (London 1999, Laird 2000, York 2002, Ehnenn 2008). ${ }^{9}$ Somerville and Ross's works have been usually read from within feminist/sexual discourse and the Anglo-Irish tradition of the Big House writing. Although these approaches are meaningful and have been fundamental in emphasising the significance of Somerville and Ross's collaboration and in tracing a history of women's co-authorship, studies of Somerville and Ross's partnership outside of these perspectives are still largely lacking. Jamison's (2016) is the first monograph entirely focussed on Somerville and Ross trying to widen the privileged discourses within which their partnership has been usually understood.

It is essential to point out that, in both collaborations, we have only one point of view available: no comment on their partnership and how it worked was made by either Besant or Rice while it was still in progress; after his partner's death, Besant waited five years before revealing some details and expressing his opinions. We do not know of any written comment on the collaboration by Rice. Similarly, readers of Somerville and Ross can find an abundance of metadiscourses by Somerville, while we have no written accounts by Martin, apart from her letters collected by Lewis 1989. My conclusions thus are necessarily based on statements made by Somerville and Besant, and it is important to keep in mind that they represent only the viewpoint of one of the partners.

Somerville's and Besant's initial attitudes towards their recently-deceased literary partners were very similar, both remembering them with sentimental nostalgia and recalling their collaborative years in idyllic terms. Strangely enough, though, with the passing of the years Besant became increasingly colder on the issue of collaboration, and over the course of the two decades he survived Rice he totally changed his perspective. Before his death, he ended up strongly advising against it. In his 285-page-long Autobiography, only seven pages are assigned to his ten-year collaboration with Rice, and his account is continuously interrupted by digressions, giving the feeling that he was unwilling to talk about it. Eventually, Besant concluded that "[i]f I were asked for my opinion as to

\footnotetext{
All the works cited so far are journal articles or essays in wider studies. Morrison (2019) is the first booklength edited collection devoted solely to Besant's achievements and writings, but only one essay (Storer 2019) discusses at length his partnership with Rice. The growing body of work published on Besant in the last few years seem to suggest that "the time is ripe for a re-evaluation" (Morrison 2019: 13). Although Besant wrote more than forty novels, only two have appeared in critical editions, both by Morrison (Besant [1882] 2012, Besant [1886] 2015).

${ }^{8}$ I shall follow a common habit among critics of Somerville and Ross of referring to both authors by "Somerville and Ross," and by "Martin" when referring to Violet Martin alone.

${ }^{9}$ These studies also provide a compelling discussion concerning gender and genre, and the complexities and differences of gendered writing and co-authorship. On this last topic, see also Aaron 1991, who discusses gender and co-authorship within a wider analysis of Charles and Mary Lamb's personal and writing relationship.
} 
collaboration in fiction, it would be decidedly against it. [...] After all, an artist must necessarily stand alone" (Besant 1902: 188). How could it be that a man who devoted a decade of his life to collaboration, whose fame derived entirely from it, and who (publicly) declared a perfect relationship with his collaborator - how could it be that such man came to express such negative views on co-authorship? This is not, curiously, a contradiction. Once examined in detail, we shall see that Besant and Rice's collaboration was already based on the individualistic principles Besant would declare later in his life.

In marked contrast, Somerville never got over the loss of her writing partner. All her postcollaborative non-fiction "is laden with elegiac praise for Martin" (Mooney 1992: 159). Over time, she fiercely stuck to her initial view of co-authorship. Famously, taking co-authorship beyond the limits of plausibility, she kept publishing under the double signature: the name "Martin Ross" is still present in every single piece written after Martin's death in 1915. Somerville claimed that Martin's death had not interrupted their collaboration, as her partner continued to communicate with her through seances. ${ }^{10}$ Somerville's 1917 autobiography Irish Memories opens with the following words: "[p]erhaps I ought to begin by saying that I have always called her 'Martin;' I propose to do so still" (Somerville and Ross 1917: 1). It is curious for an autobiography to begin by talking of someone else. Differently from Besant's autobiography - which posits Besant as an independent author and barely mentions Rice's name - Somerville's revolves around her literary partnership: it is more a joint biography of Somerville and Martin and, for this reason, it bears the double signature. While Besant pointed out that his and Rice's collaboration was never a binding one, conveniently going on from novel to novel, Somerville keeps highlighting her and her collaborator's extreme personal closeness and loving commitment. Besant's and Somerville's opposite treatments of their literary partners in their autobiographies mirror their divergent attitudes to the collaborative experience, as the following sections will show.

\section{Besant and Rice: The Artist and His Assistant}

When Walter Besant and James Rice met in $1869,{ }^{11}$ the former had just spent six years as a mathematics professor in Mauritius. Rice had studied Law, but after leaving Cambridge (where Besant had also studied) his literary ambitions had led him to seize the opportunity of buying and making himself the editor of the 3d. illustrated weekly Once a Week, "a struggling title originally set up in 1859 as a rival to Dickens's All the Year Round" (Storer 2019: 40). ${ }^{12}$ Both men had already tried their hands at novel writing; both had been unsuccessful (Besant 1894: 3-10). ${ }^{13}$ The two had literary ambitions but seemed unable to pursue them.

\footnotetext{
${ }^{10}$ On this topic, see Collis 1968: 177; London 1999: 5, 116-17; Jamison 2016: 131-65.

${ }^{11}$ Storer (2019: 40-1, note 5) notes that Besant's carelessness in dating the events of his early collaboration in his various accounts has led to confusion, and through a careful investigation proves that their meeting could not have occurred earlier than July 1869.

${ }^{12}$ Rice was editor of Once a Week from 1869 to 1873 , when he "found that it was absolutely useless to carry on Once a Week any longer; its time had gone by; no new subscribers could be caught, and the old steady readers were dying off. He parted with it, therefore, having lost more heavily by the business than he could well afford" (Besant 1887: viii).

${ }^{13}$ Besant made no mystery that his first novel had been a failure: for two years he devoted his free time to the writing of a novel that was rejected by publishers and later burned by himself. Years later, Besant turned the rejection of his first novel into a useful anecdote that corroborated his theories on the importance of "painstaking practice" (Besant 1902: xvii).
} 
On his return to London, Besant thought journalism the best option to make his way into the literary world. He started to work as a regular contributor to Once a Week, and a friendship between Besant and the editor developed. After the disastrous serialisation of a serial called The Mortimers, published in his magazine from February to October 1870, Rice had thought of another story. He had planned the plot, had drawn the main characters, and had written the first chapters: however, he must have realised that the work would not come out well this time either. He needed an ally, someone who would help him in the writing. He thought of joining forces with his paper's contributor, who could write with facility and with whom he was becoming increasingly familiar (Besant 1887: v-vii; Besant 1894: 10-11).

The collaboration began, and the first result was Ready-Money Mortiboy, first serialised in Once a Week from January to June 1872 and published the same year by Tinsley. This is perhaps the best and most representative novel by Besant and Rice, as it already presents many features of their later production. The co-authors analyse the role money plays in society: how it affects social relationships, how it can corrupt people and make them worse (as in the case of the elderly protagonist, a hardened banker) or how it can make them better (as in the case of his son Dick, the Prodigal Son). Although the novel already has some of Besant and Rice's flaws - too many digressions, the external narrator's voice often interrupting the narration in order to make a lengthy comment, and a touch of misogyny - it has none of the improbable events and the sentimentality that characterise their later work. Like many novels of the time, the influence of a good and innocent woman - the quintessential Victorian angel of the hearth - in reforming a depraved man is one of Besant and Rice's most recurrent motifs, as is the vivid portrayal of the life of the London poor, especially destitute children. This was carried over into Besant's solo fiction in his declared aspiration to follow in Dickens's steps, though the periodical press had already compared Besant and Rice to Dickens (Besant and Rice 1878, 3: n.p. review by The Examiner). ${ }^{14}$

Besant and Rice's next novels (My Little Girl 1873, With Harp and Crown 1875, The Golden Butterfly 1876, This Son of Vulcan 1876, The Monks of Thelema 1878, By Celia's Arbour 1878, The Seamy Side 1880, The Chaplain of the Fleet 1881$)^{15}$ were not only praised by critics, but also bore pecuniary fruits and circulated widely in Europe, in America and in the colonies. Their run to success, however, was suddenly interrupted by Rice's death. His fatal illness is narrated by Besant in the preface to the 1887 edition of Ready-Money Mortiboy (xi-xii) and in his Autobiography (198). Curiously, the two accounts are told in very different tones. In 1887, the story is detailed, almost repetitive, and written in a sentimental tone; one can feel the hope at Rice's improvements, the disappointments at his relapses, the renewed hope at what seemed a recovery, and the anguish at the final, unexpected decline. One feels the close bond between the two. The Autobiography, instead, presents a shorter and much more pragmatic account: Rice's ups and downs over more than a year of illness are just listed one after the other; no feelings on Besant's part are mentioned. The last words Besant ever spent on his ten years' collaborator are shockingly icy: "[a]fter lingering for six months in great suffering, he died in April 1882 at the age of thirty-nine; the cause was a cancer in the throat" (Besant 1902: 195). The tone may be due to the fact that Besant had spent the preceding twenty years trying to satisfy the press's curiosity about his collaboration, and was exhausted. Perhaps at least in his autobiography he wanted to talk only about himself (he surely had a big enough ego); it was as if Besant took the occasion to reclaim his status as an individual novelist.

\footnotetext{
${ }^{14}$ For an analysis of the parallels between Dickens's and Besant's life, work and philanthropy, see Diniejko 2019.

${ }^{15}$ On Besant's solo novels, especially All Sorts and Conditions of Men and Children of Gibeon and their philanthropic involvement with the East End, see Neetens 1990, Gannon 2014, Ginn 2017, Çelikkol 2019, Swafford 2019, Cheng and Kim 2019. On Besant's less famous solo novels see Banerjee 2014. For a discussion of the features of Besant and Rice's co-authored novels, see Boege (1956a: 257-65), Storer (2019: 49-54), and Ginn 2019.
} 
A week after Besant's death, an article appeared in The Times by Percy Fitzgerald, who claimed to have known both men and to be able explain in detail how the late novelist and his longdeceased collaborator had worked together:

Besant was the skilled writing partner - he did the description, dialogues, characters; but Rice thought out the plot and construction. They met at each other's rooms, over a pipe and glass of grog, and debated the story chapter by chapter. Rice, having read his friend's daily portion of the work, would arrive furnished with many ingenious expedients for unravelling or complicating the situation [...] Most of these were put aside, and the most striking and eligible were chosen. Besant had a gift for seizing on and developing what was thus put before him. Rice, too, often told some of his commercial efforts to exploit the stories - what elaborate treaties he entered into with the colonial booksellers, etc. In all these things Rice was the business manager and worked the 'show' thoroughly well [...]

(Fitzgerald 1901:16)

There is no reason to doubt the accuracy of Fitzgerald's account: all the other evidence supports it. In 1890, James Brander Matthews, a personal friend of Besant's and a co-author himself, had written in his essay "The Art and Mystery of Collaboration:"

I have heard [...] that of the long series of stories bearing the names of Besant and Rice, all that the late James Rice actually wrote with his own pen was the first chapter or two of their first book [...]. This assertion [...] gains color of truth from the striking similarity of style, not to call it identity, of the Besant and Rice novels with the novels of the surviving member of the partnership.

(Matthews [1890] 1891: 8-9)

Besant's own remarks on the collaboration confirm this hypothesis. He never explained in detail how the partnership had worked, but he dropped some hints. Besant's Autobiography dismissed the subject in a few but significant sentences:

the collaboration went on from one story to another always without any binding conditions, always liable to be discontinued; $[\ldots]$ The collaboration had its advantages; among others, that of freeing me, for my part, from the worry of business arrangements. I am, and always have been, extremely averse from making terms and arrangements for myself.

(Besant 1902: 187-8)

The casual, non-binding nature of collaboration seems to be a point of importance for Besant. He appears anxious to let readers know that he was never bound by any contract to Rice, but that the partnership had gone on spontaneously from novel to novel. Also, Besant confirmed that Rice had acted as a manager: he was the one who looked for and handled contracts. The literary marketplace of the late nineteenth-century was so complex that Besant felt that "outside help was needed in order to retain the artistic integrity necessary to write" (Ashton 2003: 108). According to him, indeed, the artist should not be tainted by money matters: "[a]n author is as a rule endowed with an artistic temperament; he [...] is wholly unbusinesslike in making commercial bargains" (Besant 1899: 298). Thanks to his partnership with Rice, Besant was free from the worries of practical issues and could focus solely on the production of the text. When Rice died, he lost no time in availing himself of the services of one of the first and most prominent literary agents in London, A.P. Watt. ${ }^{16}$

\footnotetext{
${ }^{16}$ The literary agent as a professional figure arrived on the scene between the late 1770 s and early $1880 \mathrm{~s}$, and was a key factor "in the radical transformation of the publishing world that occurred at the end of the nineteenth century" (Gillies 1993: 20). Gradually, the agent acquired as much influence as publishers, editors, and critics. Gillies (1993 \& 2007) recognises three men that played a central role in the agent's rise to prominence: A.P. Watt, J.B. Pinker, and Curtis Brown. Watt (1834-1914) is generally regarded as the first true agent: though he did not invent the job, he played the leading role in defining the functions of agents (Gillies 1993: 27). He acted for Collins, Hardy, Yeats, Conan Doyle, Kipling, Mrs. Oliphant, Bennet, H.G. Wells, and Rider Haggard, among others (Boege 1956a: 256; Gillies 1993: 29). Later helped by his son, he handled Besant's affairs for the rest of the novelist's career. Besant talked in positive terms of his agents, and stressed the importance of
} 
Without directly referring to his own experience, Besant theorised his position on how a literary partnership should work in the article "On Literary Collaboration," 17 which appeared in the New Review of February 1892 and which was reprinted in plenty of periodicals of that spring. ${ }^{18}$ Besant put great emphasis on the importance of discussion for the creation of a work of fiction: "the novelist can find nothing more helpful to his work than to talk it over" (Besant 1892: 208). He explained that when a situation was discussed, a thousand combinations occurred; those which were useless or unnecessary were more easily picked out and thrown away in discussion than on one's own, while the most promising were developed to their full potential.

Notwithstanding the importance of discussion, Besant strongly believed in the value of what he called the unity of impulse: "the very essence of literary partnership is that the result must appear just as spontaneous, just as entirely individual, as if it had been the creation of a single mind and the work of a single pen" (Besant 1892: 202). In other words, "the presentment of the story must seem to be by one man. [...] We must hear - or think we hear - one voice" (205). Such unity of impulse had to be attained through the domination of one partner: Besant argued that "in literary partnership, one of the two must be in authority: one of the two must have the final word" (204); so, after discussing matters, "one man must finally revise, or even write, the whole work" (205). Discussion was fundamental, "[b]ut literary style is another thing. It is individual. One of the two must impress his own individuality upon the work" (205). The man in charge of writing had to take a final decision on the points on which the partners did not agree, and had to mould the text on his taste, otherwise the work would result in a "grotesque" and "ineffective" mixture, with each character talking "with two voices and two brains" (205).

This division of tasks between Besant and Rice projects one partner as the literary "genius" and the other as the helpmate, the assistant who acts as both a mediator between the creative artist and the surrounding world, and the clerk who offers suggestions. Hence, in Besant's conception of co-authorship, the idea of the post-Romantic solitary genius remains. Archibald John StuartWortley's 1882 portrait of Besant and Rice (now in the National Portrait Gallery), intriguingly analysed in detail by Storer (2019:47-8), seems to allude to the different roles played by each partner in the collaboration: while Besant "stands stiffly [...] towering over Rice," and holds a bundle of papers in his right hand - thus confirming to be the one to do the writing and hence the one in authority? - Rice is seated at the table, smokes a cigarette, looks more relaxed and far more approachable. Besant stares away, absorbed in meditation or looking for inspiration, whereas Rice looks directly at the viewer. Each man has a glass near him: Besant's is full, Rice's is empty, which, according to Storer, could "hint at Besant's greater contribution to the actual content of the books" (48).

\footnotetext{
this professional figure: "I cannot speak too strongly of the services rendered to me by my literary agents. [...] The agent who knows his business may be of immense use to the novelist" (Besant 1902: 204); "[t]he Literary Agent has now become almost indispensable for the author of every kind, but especially for the novelist" (Besant 1899: 215). For a discussion of A. P. Watt's achievements and legacy, see Gillies 1993.

${ }^{17}$ Not every aspect of "On Literary Collaboration" will be treated in the present study: only the elements referring to the workings of a literary partnership will be dealt with. For an analysis of other parts of the article, see Bunting 2019.

${ }^{18}$ The British Newspaper Archive is very helpful in identifying reprints. In this case see, e.g., St. James's Gazette, 1 February 1892, p. 5; Yorkshire Evening Post, 2 February 1892, p. 1; Birmingham Daily Post, 2 February 1892, p. 7; Glasgow Evening Post, 2 February 1892, p. 8; Morning Post, 3 February 1892, p. 2; Inverness Courier, 5 February 1892, p. 3; Grantham Journal, 13 February 1892, p. 2. Note: these reprints are not listed in the bibliography below.
} 
In "On Literary Collaboration," Besant also crucially debated the aesthetic value of a text written in collaboration. He maintained that "two heads will prove better than one" where there was need for "construction, compressions, selection, and grouping" (Besant 1892: 201) and "clearness of purpose" (208). In storytelling collaboration "may be not only possible but useful" (204): Dickens, Collins, and Reade were able to collaborate because "these writers are first and foremost, storytellers" (204). Besant included himself in their ranks, and expressed his pride in being part of "the company" (Besant 1902: 184).

Due to the discussions and mutual criticism implied in collaboration, however, Besant warned that the result may be too distinct, the construction almost scientific, with not enough space left to the imagination:

[t]here is the danger that there may be too much distinctness - a loss of atmosphere - not enough left to the imagination. Living men and women are not always distinct; they change from day to day; they possess more than one characteristic; $[\ldots]$ That is the real danger $[\ldots]$.

(Besant 1892: 208)

Joint authorship was perceived by Besant to deprive the creative process of vagueness, spontaneity and excess, all ingredients that could lead to a masterpiece. "Satire, fun, humour, and pathos all may be exhibited at their best in partnership" (203), but, he continued, "[t]o touch the deeper things one must be alone. [...] One must, alone, speak to the alone" (203). Besant's conclusion was, therefore, that "[n]either in the study of the wanderings and development of the individual soul, nor in the development of character, nor in the work of pure and lofty imagination, is collaboration possible" (204).

Supported by other well-known collaborators, the idea that co-authorship had no claim to high literary value became widespread. Most journals seemed to agree that, if writers had talent, they had better not to collaborate. A couple of extracts will suffice to give an idea: ${ }^{19}$

A writer of high ability, or even of distinctive character, should avoid collaboration unless he is aiming, above all, at commercial success [...]. Who can fancy a writer of delicate taste, and accustomed to say things in his own way, taking a collaborator? [...] What collaborator would have dared to suggest to Victor Hugo that his interminable monologue on the portraits in Hernoni [sic] was a little long? What collaborator, again, could have touched the dialogue of 'The School for Scandal' without really injuring it? Collaboration is for authors of the second rank and under.

("Collaboration" 1886, emphasis mine)

It is not necessary here to make any estimate of the gain or loss incidental to collaboration. Of course it all depends on the collaborators, and even when these are of the best it is doubtful if the work will have the finest quality of genius. One cannot think of the 'Divina Commedia,' or 'Paradise Lost' as being the outcome of any joint effort $[\ldots]$.

("Books of the Day" 1892)

The fact that most periodicals mentioned the great classics of literature, saying that they could have never been "the outcome of any joint effort," but that on the contrary the intervention of a collaborator would have ruined them, speaks volumes. Collaboration was considered as having "served the cause of periodical literature" (Matthews [1890] 1891: 11), and nothing more. Indeed, in novels to be published in weekly or monthly parts, a requirement of paramount importance was a well-planned plot, capable of keeping the suspense up.

${ }^{19}$ For a full discussion, see Cozzi 2019. 
Even though in "On Literary Collaboration" and earlier commentaries Besant had claimed the importance of the help of a partner, in the Autobiography he declared that, after some time, every collaboration was doomed to end, due to each partner's natural desire to walk with his own legs and to enjoy fame on his own; he emphasised the restraint and the irritation each collaborator sooner or later inevitably feels at being stuck in a partnership, and stated that a writer needs to keep himself intact: after some time, collaboration only leads to dismemberment (Besant 1902: 188).

\section{Somerville and Ross: The Fortuitous Holder of the Pen}

Somerville and Ross not only did not perceive co-authorship as dismemberment, in stark contrast they experienced it as gaining wholeness. Besant's approach - the division of tasks and the predominance of one partner over the other - was fiercely rejected.

After growing up apart, the second cousins Somerville and Ross met in their mid-twenties on an occasional visit of the Martins to the Somervilles' residence in January 1886 (Somerville and Ross 1917: 120). At that time, all Somerville's energies were directed towards becoming a professional illustrator, and she has persuaded her parents to let her study art in Dusseldorf and in Paris. On her part, Violet Martin was just beginning to turn into Martin Ross. She had, like the men in her family, published a few serious articles in the Irish periodical press. When in 1886 Martin stayed at Drishane House (Castletownshend, County Cork), friendship between her and Somerville bloomed. In 1887, they engaged in the compilation of a private dictionary called the "Buddh Dictionary," a collection of words and phrases used by the network of families that descended from their great-grandfather Charles Kendal Bushe. ${ }^{20}$

The step towards a committed literary collaboration was not far, and the key to it was friendship. The summers of 1886 and 1887 built the foundation of their intimate and exclusive partnership. Their habit of going for walks and spending the mornings outdoors talking together would become a basic element of their collaborative method. By becoming friends, the two young women were actually preparing the ground for their professional career. ${ }^{21}$ It is important to remember that Victorians recognised female friendship as a much more significant social bond than contemporary society, comparable to kinship and conjugal love (Marcus 2007: 29). Before "psychiatrists popularized the concept of the deviant lesbian" (30), emotional intimacy and passionate female friendship were integral elements of domestic life (10-11, 25-6). Besides, Marcus points out, in the last decades lesbian studies have generally placed women's friendships on a continuum with lesbian relationships. This tendency, "once a powerful means of drawing attention to overlooked bonds between women, has ironically obscured [...] the important differences between female friends and female lovers" (29). In a celebrated passage, Somerville reflected that

\footnotetext{
${ }^{20}$ According to Somerville, descendants of Bushe called themselves 'Buddhs.' Somerville referred to Buddh terms as "the froth on the surface of some hundreds of years of the conversation of a clan of violent, inventive, Anglo-Irish people, who generation after generation, found themselves faced with situations in which the English language failed to provide sufficient intensity, and they either snatched at alternatives from other tongues or invented them." (Lewis 1989: 297)

${ }^{21}$ On female friendship and its various forms in the Victorian age, see Faderman 1981, Vicinus 2004 and Marcus 2007. Within her wider analysis of the community of expatriate women poets living in Florence in the 1840 s and 1850s, Chapman 2015 explores the intellectual, social and sometimes homoerotic bonds that these women shared; she also considers some cases of female cohabitation - described as female marriages - that provided mid-Victorian women writers living in Italy with opportunities to reimagine their identity in creative, fertile and liberating ways.
} 
[t]he outstanding fact [...] among women who live by their brains, is friendship. A profound friendship that extends through every phase and aspects of life, intellectual, social, pecuniary. Anyone who has experience of the life of independent and artistic women knows this.

(Somerville and Ross 1917: 326)

Female friendship is declared to be fundamental for women's intellectual, social, and even financial condition. If a woman chose to be independent, then friendship with other women in her same situation was what, according to Somerville, provided the emotional support she would need. Studies of New Women in America and Britain generally distinguish between a first and a second generation. The first generation was born in the 1850 s and $1860 \mathrm{~s}$; educated, autonomous and single, they were active in the feminist movement from the 1890s to WWI, "sought personal and economic independence by rejection of their mothers' domestic roles," and "turned to romantic friendships as the alternative" to the male-dominated, heterosexual family structure (Newton 1989: 238; see also Smith-Rosenberg 1985: 245-96). In this light, Somerville and Ross fit into the historical category of first-generation New Women (Mooney 1992: 171). Somerville had already experienced mutually supportive female friendships in her Paris days, when she had shared house and expenses with other "independent and artistic" young women. With Martin, she took the concept to a further level, making their friendship the most significant relationship of her life and the underlying rock of her career. ${ }^{22}$ Somerville spoke of their bond as a perfect union in overtly romantic terms. Recalling their first meeting she wrote:

it has proved the hinge of my life, the place where my fate, and hers, turned over, and new and unforeseen things began to happen to us.

(Somerville and Ross 1917: 122)

For most boys and girls, the varying, yet invariable, flirtations, and emotional episodes of youth, are resolved and composed by marriage. To Martin and to me was opened another way, and the flowering of both our lives was when we met each other.

(Somerville and Ross 1917: 125)

Somerville would write to her brother after Martin's death that "[n]o one but ourselves can ever know what we were to each other" (quoted in Mooney 1992: 159). The friendships she would make in the next three decades with the medium Geraldine Cummins (who would be her first biographer) and with other women in no way approached the intensity and the commitment of her connection with Martin. The peculiar nature of their relationship has led critics to infer that a sexual relationship existed between Somerville and Ross, and many studies have struggled to either prove or negate their lesbianism. Mooney (1992: 157) points out that the study of Somerville and Ross's life and work has been inevitably "hampered by heterosexist, if not homophobic discomfort with the question of lesbianism their relationship raises," and specifically examines how biographers Collis (1968)

\footnotetext{
${ }^{22}$ They were not the only ones. In the second half of the nineteenth century, employment opportunities for women, though still limited, increased, and a woman with ability and motivation could make her way as she seldom could have done in earlier times. This opportunity, and the choice to live for their personal goals most of the time of an artistic nature - led many women not to marry. A new class of women started to rise, pioneers who obtained their position not by virtue of any connection to a father or a husband but only by their own efforts (Faderman 1981: 204-05). Even though many women artists believed marriage to be incompatible with their life ambitions - the "ultimate impediment to their professional creative practices" (Rose 2018: 14) - there were some notable exceptions, like Mary Seaton Watts (1849-1938) and Evelyn De Morgan (1855-1919) who, though married, formed unconventional creative partnerships with their husbands, respectively George Watts and William De Morgan. Far from being self-sacrificing, submissive helpmates, Mary Watts and Evelyn De Morgan were active and influential in their anti-patriarchal partnerships: in these relationships, "both figures functioned as supporter and supported, professional artist and domestic partner" (Rose 2018: 11).
} 
and Lewis (1985) have represented these women's connection with "inherent heterosexism" (160). Collis states categorically that "Somerville could only fall in love with a woman" (1968: 37) and depicts her as a man-hating lesbian (32-33). After Collis 1968, others have characterised their relationship as lesbian, like Stone and Thompson 2006, Wood 1994, and York 2002. Lewis (1985 \& 2005), the other hand, like Somerville's first biographer Cummins (1952), strongly negates the sexual nature of their relationship and defines it a sisterly kind of affection, rejecting any hint of sexual "deviance", and so do a number of other studies like those by Cahalan 1999, Cowman 1997, Kiberd 1996, Kreilkamp 2010, London 1999, O’Connor 2010, and Weekes 1990. The aim of my study is not to try to infer whether or not Somerville and Ross were homosexual. Firstly, because it is simply impossible, since to read with twenty-first century eyes the declarations of Victorian women who were immersed in a totally different cultural atmosphere becomes a matter of speculation. Secondly, and more importantly, because it does not matter: whatever the sexual nature of their relationship, what is relevant to this study is what Somerville and Ross considered vital for their literary career: it was the spiritual and emotional aspect of their union, the constant affection, encouragement and support, and the intellectual affinity that made their daring life choices possible and their literary collaboration successful. They strongly believed that, without their friendship, their achievements as "women who live by their brains" would have been impossible. Ultimately, I agree with Mooney (1992: 173) that using "unhelpful heterosexist bias" in order to prove or disprove lesbianism "obscure[s] and distort[s] the creative, emotional and probably sensual centrality of the[ir] relationship."

The literary marketplace of the late 1880s was full of shilling shockers, and Somerville and Ross thought it would be funny to try their hands at something of that kind. Thus, they began "what was to be known to us as 'The Shocker,' [...] to our family generally as 'that nonsense of the girls,' and subsequently, to the general public, as "An Irish Cousin"" (Somerville and Ross 1917: 128). Somerville claims that their joint venture began "in idleness and without conviction" (129), as something they did for the fun of it. ${ }^{23}$ To the young women's amazement, the book was accepted and published by Bentley in 1889. Reflecting on the meaning the writing of the novel had had for her, Martin vividly recognized its importance in both their lives:

[a]ny period of good work has a nice honest romance about it. [...] You once said a little thing about it and what the writing of it did for us - if you don't remember it I do - that is good enough. Anyhow it was a nice little thing.

(Letter from Martin to Somerville, 3 December 1887, Lewis 1989: 62).

Martin reflected on the personal gains of their joint literary activity, the "nice little thing" that it did for them: the physical product of their partnership, the novel itself, does not seem as important as the experience of the collaboration. This is totally at odds with Besant and Rice's first experience as co-authors, aimed at selling a product and intended to achieve a target that each had been unable to do alone.

\footnotetext{
${ }^{23}$ Similar claims are common to many women co-writers when they recount their beginnings. For instance, the sisters Emily and Dorothea Gerard, who wrote under the pseudonym E.D. Gerard, claimed that they had started to write together out of the necessity of having "something to do" (Black 1896: 155). From many accounts of women co-authors, the practice of collaboration emerges as a form of private entertainment, something started without any serious literary intent. This might be ascribed to notions of Victorian femininity and respectability: it was safer to say that their literary beginnings were an unpretentious pastime. On the complicated relationship between gender, creativity and professionalism, see Hadjiafxendi and Zakreski 2013, a collection that explores concepts of professional identity for women during the long nineteenth century. It calls attention to the fact that there were continued backlashes against female professional activities, and dismisses the naïve idea that there was continuous progress for women from amateurs to professionals.
} 
Begun in imitation of the fashionable shilling shockers, An Irish Cousin turned out to be much more, perfectly fitting the best tradition of the Irish Gothic. ${ }^{24}$ The glowing reviews by London magazines struck the incredulous amateurs, and reinforced their purpose to become co-authors. Bentley offered them $£ 100$ for a three-volume novel, and they set out to write their masterpiece, The Real Charlotte. Its composition was intermittent, and took three years of erratic spells. By then, the offer of $£ 100$ no longer seemed adequate to the cousins, who "wrote breathing forth fire and fury, and refused" (Somerville and Ross 1917: 232). Only five years before, they had accepted in dizzy incredulity $£ 25$ for their debut novel; now their confidence had grown, and the awareness of the value of their work made them reject four times that sum. They believed that The Real Charlotte was their best work, a certainty that would remain steady for the rest of their lives (238). This was the beginning of Somerville and Ross's self-perception as professional writers. They began a process of negotiations with different publishers, and The Real Charlotte was finally sold to Ward and Downey for $£ 250$ and published in 1894. Soon reviews started to appear. They were bad: the lack of at least one positive figure, of lofty feelings, and of a pure love affair found no favour with the press.

The Real Charlotte revolves around two women, the Machiavellian Charlotte and her cousin Francie. Charlotte and Francie are each other's opposites and embody two different models of femininity: Francie is a conventionally beautiful girl, playful, naïve and "incessantly enmeshed in the most lurid flirtation" (Somerville and Ross 1917: 92); Charlotte is a middle-aged unmarried woman, painfully unattractive, greedy and cynical. Francie yearns for love; Charlotte strives to climb the social ladder. There is no happy ending for either of them, nor for any of the other characters who inhabit the middle-class pettiness of Anglo-Irish society. The novel's grimness - enlivened by Somerville and Ross's caustic wit - made it stand out from the majority of the popular novels of the time. Although it did not please critics, it was quite a success with the public and scored "steadily improving sales" (Somerville and Ross 1917: 241).

The cousins decided to write another novel, a second "ferocious narrative" (252), this time focused on the contrast between the Anglo-Irish and the English. It was settled that the new novel should appear in weekly instalments, a choice that did not fit Somerville and Ross's writing practices, as serial publication involved a steady rate of production which was not compatible with their lives. The Silver Fox (1897) was written in a hurry, among the usual interruptions. By the time they had started to write it, Somerville and Ross were set on making a living for themselves out of literature. To this purpose, they decided to avail themselves "of all of authorship's new institutional structures" (London 1999: 110). They were among the first women to join Besant's Society of Authors. They hired James B. Pinker who was, along with Watt, one of the most prominent agents of the time. The decision to hire an agent again points to Somerville and Ross's self-perception: the two girls writing a shilling shocker hiding in the kitchen garden between rows of cabbages (Somerville and Ross 1946a: 84) had turned into professional women writers. Now, they "had a taskmaster, a little man of iron determination, a Literary Agent (which is the modern equivalent for an Egyptian taskmaster)" (Somerville and Ross, 1946b: 9). The choice of hiring Pinker and not another agent was significant as well. Jamison (2016: 83) stresses that Pinker distinguished himself from the model of agenting established by Watt by pursuing a different kind of client. Gillies (2007) takes Somerville and Ross as a case study to investigate Pinker's professional relationship with his clients: he was well-known for representing young writers and female authors; if Watt tended to be less willing to work with writers "for whom there was not a ready-made audience" (Gillies 1993: 29),

\footnotetext{
${ }^{24}$ Kreilkamp (2006: 67) illustrates how Charles Maturin, Sheridan Le Fanu, Bram Stoker and Somerville and Ross developed full-blown Protestant Gothic Big House novels, and identifies four characteristic motifs: "deranged and demonised landlords, settings in decaying houses, a growing class obsession with racial pollution and cultural decline, as well as sadistic threats against helpless young women."
} 
Pinker made himself a name for his championing of new names in literature and of women (Gillies 2007: 93). ${ }^{25}$ Watt's client list was "conservative in the sense that his authors reflected the prevailing taste of the general reader" (Gillies 1993: 29). Moreover, differently from Watt, who acted as an agent for both authors and publishers, Pinker worked only for authors (Gillies 1993: 23). In this way, he made himself a name for defending authors' rights against the snares of the publishing trade (Gillies 2007: 90-3) and gained renown as "the writer's agent" (Gillies 1993: 31). ${ }^{26}$

Pinker managed to secure for Somerville and Ross some of their most lucrative publishing deals. As a matter of fact, money was an increasingly pressing issue. By the end of the 1890s, they were in their mid-30s, had no intention of getting married, and had their families' country estates to run. The desire of the two women for financial independence was stronger than ever. However, the turn in Somerville and Ross's career from amateurs to professionals might be what, ironically, limited their subsequent literary output, as Somerville repeatedly claims in Irish Memories. After The Silver Fox, the duo did not embark upon the writing of any other novel for more than a decade. Their next and last joint novel, Dan Russel the Fox, appeared only in 1911, and in reading it one has the feeling that something is missing; the novel betrays lack of concentration, and basically results in "an episode," as the subtitle recites. The reason for the long silence between The Silver Fox and Dan Russel the Fox is that, just after the publication of the former, Somerville and Ross devoted themselves to the short stories that would become their hallmark: the twelve stories about the adventures of the hilarious Irish Resident Magistrate, Major Sinclair Yeates, were published monthly in the Badminton Magazine and collected in book form in 1899 under the title Some Experiences of An Irish R.M. The invention of the R.M. gave the cousins a steady stream of income, also thanks to continuous re-editions and the sequels that followed (collected in Further Experiences of the Irish R.M. in 1908 and In Mr. Knox's Country in 1915).

Despite their wish to write what they called "serious" literature, their agent and their families encouraged them to go on with humorous hunting stories, as they sold well and were quicker to write:

[t]hey all - including the little Pinker - swore we had got hold of a very good thing in this serio-comic hunting business - 'To use literary slang,' said Pinker, 'this is your own stuff \& no one else does anything like it -' [...].'

(Letter from Somerville to Martin, 25 April 1897, in Lewis 1989: 243)

Somerville admitted to her brother Cameron that the stories were "such good business that we can't afford to fall out with them" and that "only that we both want money so badly we would chuck them for the present" (quoted in Jamison 2016: 102). The appetite of the public for the humorous stories of Irish life and fox-hunting was great, and continued well into the twentieth century. The "dirty Irish realism" (Lewis 1989: 25) of The Real Charlotte did not sell as much.

\footnotetext{
${ }^{25}$ On Pinker's client list we find, among others, Conrad, Joyce, Lawrence, James, Katherine Mansfield, Alice Williamson, Rebecca West, Dorothy Richardson and George Egerton (Gillies 1993: 29). His attitude towards women's suffrage was something that Somerville and Ross appreciated and used to discuss with him (Gillies 2007: 93).

${ }^{26}$ This does not mean, of course, that Watt acted more in the interests of publishers: as Gillies $(1993,25)$ points out, "he probably would have agreed that agents who took a fee from publishers for placing a work with them were unethical." Watt set a standard of honesty and integrity by which his successors were measured (Gillies 1993, 30).
} 
After being badly hurt in a riding accident in 1898, Martin had to spend several months in bed as an invalid and could write only desultorily. Her already weakened health never fully recovered: ${ }^{27}$ in the following years "it was impossible for her to undertake any work that would demand steady application" (Somerville and Ross 1917: 294). The two women started to spend long periods in health spas, often in France, also because Somerville was beginning to suffer from the rheumatism that eventually crippled her.

In the last chapter of Irish Memories, Somerville went back once again to their frustrated desire of writing "serious novels":

[t]o return to our work, which for us, at all events, if for no one else, was serious. [...] I suppose it was the result of old habit [...] but, for whatever reason, during the years that followed the appearance of 'Dan Russel the Fox,' Martin and I put aside the notions we had been dwelling upon in connection with 'a serious novel,' and took to writing 'R.M.' stories again.

A sentence like "our work, which for us, at all events, if for no one else, was serious" in an autobiography written in a light and humorous tone betrays a not-even-veiled indignation towards the treatment their literary work had received. As a matter of fact, when it came to an overall evaluation of their professionalism, their reputation as women collaborators and humorous writers demeaned them. Many of Somerville and Ross's contemporaries and subsequent critics denied them the status of authors worthy of serious consideration. Significantly, in a not-so-strange coincidence, Somerville and Ross's "own stuff," as Pinker shaped it, was exactly the type - satire, fun, humour at which collaboration had been deemed successful by Besant and by the periodical press in general. Yet, even though Experiences of An Irish R.M is a brilliant example of comic short fiction, it was simply not the kind of literature the two cousins had wanted to build their reputation upon. They felt they had somewhat remained stuck with it.

The two women's ideas about the workings of a collaboration and its results were not aligned at all with those made popular by Besant. In Irish Memories, we can find the clearest description of their writing process Somerville ever gave, in which she claimed that it drew heavily on conversation:

[t]he question $[\ldots]$ as to which of us held the pen has ever been considered of the greatest moment, and, as a matter of fact, during our many years of collaboration, it was a point that never entered our minds to consider. To those who may be interested in an unimportant detail, I may say that our work was done conversationally. One or the other - not infrequently both, simultaneously - would state a proposition. This would be argued, combated perhaps, approved, or modified; it would then be written down by the (wholly fortuitous) holder of the pen, would be scratched out, scribbled in again; before it found itself finally transferred into decorous MS. it would probably have suffered many things, but it would, at all events, have had the advantage of being well aired.

Like Besant, discussion between the partners was essential, but for Somerville and Ross it was the very heart of their collaboration. The act of talking was accorded special significance: the writing was secondary, and was not as important as the discussion that preceded and followed it. Moreover, the role of the "holder of the pen" was neither Somerville's nor Martin's exclusively: it was "wholly fortuitous." Once they had made up their minds upon the course of a chapter, or any other issue,

\footnotetext{
27 "One of the pummels of the saddle had bruised her spine, and the shock to a system so highly-strung as hers was what might be expected. [...] The effects of the hunting accident, and the strain of writing, too soon undertaken, were [...] beginning to come to their own. Neuralgia, exhaustion, backaches, and all the indescribable miseries of neurasthenia held her in thrall" (Somerville and Ross 1917: 260-3).
} 
it was chance that dictated who wrote it down. Against the significance accorded in the Victorian imagination to the writer with his pen in hand - "that autocratic, commanding pen, which has - as is so generally known and believed - so much in its power!" (Somerville and Ross 1946a: 186) Somerville bluntly downplayed the pen as a matter of pure chance.

Crucially, it simply did not matter who had written what, because they used to plan and to revise everything together: after one had written a part, the other would always revise it, and suggest corrections and alterations; then they would write it all down once again, and so on, until they both agreed on everything. As a result, the identification of who first wrote something lost its value in the process of mutual revision.

Joint draft manuscripts reveal the extent of the authors' revisions, but we can learn little from them about the creative process. Somerville and Ross used to write on the right-hand page, with the left-page left blank for annotations (Pepinster Greene 2016: 203). The drafts do not help 'decollaborating' Somerville and Ross because their handwritings are virtually indistinguishable: London (1999: 73) notes that collaborators often come to write like each other, even displaying calligraphy that is strikingly similar. As one would expect, the manuscripts are chaotic, but, significantly, "the fluency with which they are written indicates [...] that most of the early invention and composition stages were done conversationally and not written down" (Pepinster Greene 2016: 203). So, apart from some passages in the surviving letters, we can have no written testimony of the creative process as it went on.

Another aspect of these women's collaboration is worth noting:

[w]e had sat in the cliffs, in heavenly May weather [...]. We and the dogs had achieved as much freedom from social and household offices as gave us the mornings, pure and wide, and unmolested. There is a place in the orchard at Drishane that is bound up with those final chapters [of The Real Charlotte], when we began to know that there could be but one fate for Francie.

(Somerville and Ross 1917: 231)

This extract tells us of a habit of Somerville and Ross: they wrote a lot outdoors. This may seem a trifling detail, but actually speaks volumes about their life: within the house they would always be interrupted, their attention would always be requested by their families. If a man was closed up in his study, nobody would go and disturb him; if a woman did the same, her privacy would seldom be respected. Only by fleeing outside, among nature, could they find a space for themselves (Somerville and Ross 1917: 258, 305).

Somerville and Ross's partnership debunks in many ways the conventional image of the solitary author. One may try to imagine and contrast the scenarios described by Somerville with the iconic 1839 painting of Dickens by Daniel Maclise, later engraved by William Finden: there the author is sitting alone by his desk with a meditative expression, in the undisturbed silence of what is maybe his study, thinking (or listening to the Muses?), his hand touching a manuscript, pen on the desk, ready to write when inspiration comes. In Somerville and Ross's case, instead of a single male author, we find two women; instead of writing under inspiration, in silence, they talk and discuss before and after the proper writing; instead of sitting at a desk in a room, they often create their stories in unconventional, outdoor settings, rambling outside the garret of the Romantic mythology. The creative moments could not be more different. 
In "Two of a Trade," Somerville portrayed the collaborative moments she had experienced with Martin as a sort of shared dance:

[s]ometimes the compelling creative urge will come on both, and we would try to reconcile the two impulses, searching for a form into which best to cast them - one releasing it, perhaps as a cloudy suggestion, to be caught up by the other, and given form and colour, then to float away in a flash of certainty, a completed sentence - as two dancers will yield to the same impulse, given by the same strain of music, and know the joy of shared success.

Drawing on her painting background, Somerville argued that their styles were as different as blue and yellow on the mixing palette, but that the final product was neither blue nor yellow: it was green. Exactly as green is a secondary colour resulting from the merging of two primary colours, so was Somerville and Ross's joint text: the "resultant green" obscured the individual colours that went into its composition and stood on its own, defying any untangling of the two hands involved (186).

\section{Exalting Collaboration, Demeaning Collaboration}

In the light of what we have seen so far, some conclusions can be drawn. Besant and Rice badly wanted to become novelists, and thought of collaboration as a means to succeed in what they had failed to do alone. Collaboration meant for them to join forces in order to achieve a common goal. In contrast, neither Somerville nor Martin had thought of a career in fiction before becoming friends. The two cousins started the collaboration as a result of their friendship, not as a means to achieve something.

Notwithstanding his ten years of productive collaboration, Besant stated that every writing partnership was condemned to end, since the partners would lose half of themselves in prolonged collaboration. In his Autobiography (189), he declared that, had Rice not died, the collaboration "would have broken down" anyway, although "amicably." In Besant's perception, co-authorship leads to a sort of mutilation. At a certain point, the desire to regain one's wholeness becomes stronger than the fear of failure. Conversely, neither Somerville nor Ross ever expressed the wish to enjoy fame on their own and went on to write jointly for three decades. Collaboration meant for them a merging of their individualities in order to gain a fuller unity in which each one was stronger.

The ways in which Besant and Rice and Somerville and Ross carried out their respective collaborations seem to start from a common basis only to take different paths. Discussion was vital in both cases, and both Besant and Somerville emphasised it. However, in order to achieve a cohesive text, the artistic predominance of one of the partners was deemed necessary by Besant. In this case, even though we are talking about co-authorship, the idea of the genius remains. Somerville and Ross's letters and commentaries, however, attest to their conversational method as the secret to their success. Their collaborative dance challenged the most pervasive and long-accepted notions of what an author was and should be. The theoretical implications of these women's understanding of coauthorship as merging were innovative and powerful: the figure of the author that emerges from their collaboration fades away into a hybrid and elusive figure, a sort of ghost that, according to the coauthors themselves, must remain concealed behind the text - the resultant "green." 28

\footnotetext{
${ }^{28}$ For a comprehensive discussion of the innovative author-figure proposed by Somerville and Ross's collaboration, see Cozzi 2018.
} 
Somerville and Ross were by no means the only case of late Victorian literary collaboration in which the dissolution of the Romantic idea of the author took place. Assertions of merging, seamlessness and ecstatic fluidity of the authorial identity are present in other collaborators' metadiscourses. Michael Field expressed similar views, describing their joint works as a "perfect mosaic" (quoted in Sturgeon 1922: 47) and echoing Somerville's image of the partnered dancing: "we cross and interlace like a company of dancing summer flies. If one begins a character, his companion seizes and possesses it; if one conceives a scene or a situation, the other corrects, completes, and murderously cuts away" (quoted in London 1999: 70). ${ }^{29}$ Another late Victorian literary couple, that of Vernon Lee with Clementina 'Kit' Anstruther-Thomson, employed metaphors of collaborative writing as dancing: "we are forever meeting, crossing, encroaching" (quoted in Ehnenn 2008: 172) ${ }^{30}$ However, it must be noted that these partnerships do not insert themselves into the popular market: both were associated with turn-of-the-century aesthetes whose work circulated among intellectual elites. Somerville and Ross were the only popular novelists of the time to promote a dialogic and intersubjective model of authorship aimed at deleting the status accorded by Victorian culture to authorial names, faces, and personalities.

In his widely-read 1892 essay, Besant denied collaboration any claim to high literary value. He demeaned collaboration in the eyes of the public, and consequently demeaned his own work. Somerville and Ross fervently opposed this conception, and believed in the artistic significance of their texts. Still they too unwittingly contributed to debasing collaboration: Somerville lamented that, with time, they had ended up adjusting to the market's demands and expectations and, despite their noteworthy more serious fiction, they had become widely known through their humorous, light pieces. In this way, she felt that they had confirmed contemporary beliefs about the limits of collaboration.

The apparently parallel collaborations of Besant and Rice and of Somerville and Ross are, at a closer look, quite different, if not even irreconcilable. Their literary relationships represent two models, both influential and significant, of understanding co-authorship in the late Victorian period. As the present research developed, it became clear that it meant more than tracing a history of some authors and their texts: it meant recovering and exploring an actual cultural phenomenon and the impact it had on the late Victorian discourses of writing and authorship, on how people imagined authors and their activity. Thus, the cases discussed here may offer new and challenging insights into the history of authorship, the literary market and the culture of the late Victorian era.

\footnotetext{
${ }^{29} \mathrm{Also}$, Bradley and Cooper warned readers eager to uncover traces of the respective contributions, in marital and religious terms: "as to our work, let no man think he can put asunder what God has joined" (quoted in Ehnenn 2008: 31).

${ }^{30}$ The recurrence of discourses of merging and fluidity in women's collaborations may point to a gender peculiarity, an aspect advanced first by London 1999, then by Ehnenn 2008. Considering a wide range of women collaborators in the nineteenth and early twentieth centuries, London suggests that "for women writing together $[\ldots]$ combining 'as one' would seem to be the trope they most insistently appeal to in describing their joint creations" (69).
} 


\section{Bibliography}

Aaron, Jane. 1991. A Double Singleness: Gender and the Writings of Charles and Mary Lamb. Oxford: Clarendon Press.

Ashton, Susanna. 2003. Collaborators in Literary America 1870-1920. Hampshire: Palgrave Macmillan.

Banerjee, Jacqueline. 2014. “'The Conduct of Life' in Walter Besant's 'The Ivory Gate' and 'The Alabaster Box." English Studies, 95.8: 890-906. DOI: 10.1080/0013838X.2014.942091

Besant, Walter, and James Rice. 1872. Ready-money Mortiboy. A Matter-of-fact Story. 3 vols. London: Tinsley Brothers.

Besant, Walter, and James Rice. 1878. By Celia's Arbour. A Tale of Portsmouth Town. 3 vols. London: Sampson Low \& Co.

Besant, Walter. [1882] 2012. All Sorts and Conditions of Men, edited by Kevin A. Morrison. Brighton: Victorian Secrets.

Besant, Walter. [1886] 2015. Children of Gibeon, edited by Kevin A. Morrison. San Diego, CA: Cognella.

Besant, Walter. 1887. Preface to Ready-money Mortiboy. A Matter-of-fact Story, by Walter Besant and James Rice, v-xii. London: Chatto \& Windus.

Besant, Walter. 1892. "On Literary Collaboration.” The New Review, 6.33: 200-09.

Besant, Water. 1894. "Ready-Money Mortiboy.” In My First Book, edited by Jerome K. Jerome, 3-14. London: Chatto \& Windus.

Besant, Walter. 1899. The Pen and the Book. London: Thomas Burleigh.

Besant, Walter. 1902. Autobiography of Sir Walter Besant. London: Hutchinson \& Co.

Black, Helen C. 1896. Pen, Pencil, Baton, and Mask: Biographical Sketches. London: Spottiswoode \& Co.

Boege, Fred W. 1956a. "Sir Walter Besant. Novelist. Part One." Nineteenth-Century Fiction, 10.4: 249-80.

Boege, Fred W. 1956b. "Sir Walter Besant. Novelist. Part Two." Nineteenth-Century Fiction, 11.1: 32-60.

Bivona Dan, and Roger B. Henkle. 2006. The Imagination of Class: Masculinity and the Victorian Urban Poor. Columbus: Ohio State University Press, 67-103.

"Books of the Day. An Eccentricity of Collaboration. The Fate of Fenella." 1892. (3 June): 2.

Boucharenc, Myriam. 2000. "Plural Authorship in Automatic Writing." In Subject Matters: Subject and Self in French Literature from Descartes to the Present, edited by Paul Gifford and Johnnie Gratton, 100-14. Amsterdam: Rodopi.

Buckton, Oliver S. 2007. Cruising with Robert Louis Stevenson: Travel, Narrative, and the Colonial Body. Athens: Ohio University Press.

Bunting, Kirsty. 2019. "Besant and Collaboration." In Walter Besant: The Business of Literature and the Pleasures of Reform, edited by Kevin A. Morrison, 19-38. Liverpool: Liverpool University Press.

Cahalan, James M. 1999. Double Visions: Women and Men in Modern and Contemporary Irish Fiction. Syracuse: Syracuse University Press.

Çelikkol, Ayse. 2019. "Workers as Artists: From Copyright to the Palace of Delight in Besant's Writings." In Walter Besant: The Business of Literature and the Pleasures of Reform, edited by Kevin A. Morrison, 131-47. Liverpool: Liverpool University Press.

Chapman, Alison. 2015. Networking the Nation: British and American Women's Poetry and Italy, 1840-1870. Oxford: Oxford University Press.

Cheng, Vicky, and Haejoo Kim. 2019. "From Happy Individuals to Universal Sisterhood: Active Reforms in 'All Sorts and Conditions of Men' and 'Children of Gibeon." In Walter Besant: The Business of Literature and the Pleasures of Reform, edited by Kevin A. Morrison, 187-202. Liverpool: Liverpool University Press. 
Colby, Robert A. 1990. "Harnessing Pegasus: Walter Besant, 'The Author' and The Profession of Authorship." Victorian Periodicals Review, 23.3: 111-20. JSTOR: http://www.jstor.org/stable/20082464

"Collaboration”, 1886. St James's Gazette (6 September): 6.

Collis, Maurice. 1968. Somerville and Ross: A Biography. London: Faber and Faber.

Cowman, Roz. 1997. "Lost Time: The Smell and Taste of Castle T." In Sex, Nation and Dissent in Irish Writing, edited by Eibhear Walshe, 87-102. Cork: Cork University Press.

Cummins, Geraldine. 1952. Dr. E. E. Somerville: A Biography. London: Andrew Dakers.

Cozzi, Annachiara. 2018. "The Dissolution of the Author in Literary Collaboration: Two Case Studies." Altre Modernità, 19 (May): 12-26. DOI: https://doi.org/10.13130/2035-7680/10104

Cozzi, Annachiara. 2019. "Literary Collaboration and the Late Victorian Imagination." Il Confronto Letterario, 71.1: 93-116. http://www.ibisedizioni.it/prodotto/literary-collaboration-and-the-latevictorian-imagination/

Cozzi, Annachiara. 2020. "Literary Collaboration in late-Victorian Britain." PhD dissertation, University of Pavia.

DeVine, Christine. 2002. "The Fiction of Class at the Fin de Siécle: Walter Besant and George Gissing." Gissing Journal, 38.2: 21-9.

Diniejko, Andrzej. 2019. "Walter Besant: A Latter-Day Dickens?” In Walter Besant: The Business of Literature and the Pleasures of Reform, edited by Kevin A. Morrison, 225-42. Liverpool: Liverpool University Press.

Eagleton, Terry. 2005. The English Novel: An Introduction. Malden, MA: Blackwell.

Ede, Lisa, and Andrea Lunsford. 1990. Singular Texts/Plural Authors: Perspectives on Collaborative Writing. Carbondale, IL: Southern Illinois University Press.

Ehnenn, Jill. 2008. Women's Literary Collaboration, Queerness, and Late-Victorian Culture. Aldershot: Ashgate.

Eliot, Simon. 1987. “'His Generation Read His Stories:' Walter Besant, Chatto \& Windus, and 'All Sorts and Conditions of Men."' Publishing History, 21: 25-67.

Eliot, Simon. 1989. "Unequal Partnerships: Besant, Rice and Chatto, 1876-82." Publishing History 26: 73109.

Eliot, Simon. 1999. “Author, Publisher and Literary Agent: Making Walter Besant's Novels Pay in the Provincial and International Markets of the 1890s." Publishing History 46: 35-65.

Faderman, Lilian. 1981. Surpassing the Love of Men. Romantic Friendship and Love between Women from the Renaissance to the Present. London: The Women's Press.

Faulk, Barry J. 2004. Music Hall and Modernity: The Late-Victorian Discovery of Popular Culture. Athens: Ohio University Press, 111-41.

Fitzgerald, Percy. 1901. "The Late Sir Walter Besant.” The Times, 17 June: 16.

Gannon, Christiane. 2014. "Walter Besant's Democratic Bildungsroman." Narrative, 22.3: 372-94. DOI: http://dx.doi.org/10.1353/nar.2014.0020

Ghosh. Tanushree. 2017. “'Witnessing Them Day after Day:' Ethical Spectatorship and Liberal Reform in Walter Besant's 'Children of Gibeon." In Philanthropic Discourse in Anglo-American Literature, 1850-1920, edited by Frank Q. Christianson and Leslie Thorne-Murphy, 162-89. Bloomington: Indiana University Press.

Gillies, Mary Ann. 1993. “A.P. Watt, literary agent.” Publishing Research Quarterly, 9 (March): 20-33. DOI: https://doi.org/10.1007/BF02680630

Gillies, Mary Ann. 2007. The Professional Literary Agent in Britain, 1880-1920. Toronto: University of Toronto Press.

Ginn, Geoffrey A.C. 2017. Culture, Philanthropy and the Poor in Late-Victorian London. Abington: Routledge.

Ginn, Geoffrey A.C. 2019. "Altruism and 'The Monks of Thelema:' Ideals and Realities." In Walter Besant: The Business of Literature and the Pleasures of Reform, edited by Kevin A. Morrison, 151-70. Liverpool: Liverpool University Press. 
Hadjiafxendi, Kyriaki, and Patricia Zakreski, eds. 2013. Crafting the Woman Professional in the Long Nineteenth Century: Artistry and Industry in Britain. Aldershot: Ashgate.

Hensley, Nathan K. 2013. "What is a Network? (And Who is Andrew Lang?)." Romanticism and Victorianism on the Net, 64 (October). DOI: https://doi.org/10.7202/1025668ar

Hensley, Nathan K. 2015. "Andrew Lang and the Distributed Agencies of Literary Production." Victorian Periodicals Review 48.3: 359-82. DOI: http://dx.doi.org/10.1353/vpr.2015.0045

Jamison, Anne. 2016. E. OE. Somerville \& Martin Ross. Female Authorship and Literary Collaboration. Cork: Cork University Press.

Joyce, Simon. 1996. "Castles in the Air: The People's Palace, Cultural Reformism, and the East End Working Class.” Victorian Studies, 39.4: 513-38. JSTOR: http://www.jstor.org/stable/3828935

Karell, Linda K. 2008. Writing Together/Writing Apart. Collaboration in Western American Literature. Lincoln: Nebraska University Press.

Keating, P.J. 1973. "Fact and Fiction in the East End." In The Victorian City: Images and Realities, edited by H.J. Dyos and Michael Wolf, vol. 2, 585-602. London: Routledge.

Kiberd, Declan. 1996. Inventing Ireland: The Literature of the Modern Nation. New York: Vintage.

Koestenbaum, Wayne. 1989. Double Talk: The Erotics of Male Literary Collaboration. London: Routledge.

Kreilkamp, Vera. 2006. "The Novel of the Big House." In The Cambridge Companion to the Irish Novel, edited by John Wilson Foster, 60-77. Cambridge: Cambridge University Press.

Kreilkamp, Vera. 2010. "The Novels of Somerville and Ross." In A Companion to Irish Literature, edited by Julia M. Wright, vol. 2: 50-65. Hoboken, NJ: Wiley-Blackwell.

Laird, Holly. 2000. Women Co-authors. Urbana: University of Illinois Press.

Lewis, Gifford. 1985. Somerville and Ross: The World of the Irish R.M. New York: Viking.

Lewis, Gifford, ed. 1989. The Selected Letters of Somerville and Ross. London: Faber \& Faber.

Lewis, Gifford. 2005. Edith Somerville: A Biography. Dublin: Four Courts Press.

London, Bette. 1999. Writing Double. Women's Literary Partnerships. Ithaca: Cornell University Press.

Masten, Jeffrey. 1997. Textual Intercourse: Collaboration, Authorship, and Sexualities in Renaissance Drama. Cambridge: Cambridge University Press.

Marcus, Sharon. 2007. Between Women: Friendship, Desire, and Marriage in Victorian England. Princeton: Princeton University Press.

Matthews, James Brander. [1890] 1891. "The Art and Mystery of Collaboration." Introduction to With My Friends. Tales Told in Partnership, by James Brander Matthews, H.C. Bunner, Walter Herries Pollock, George H. Jessop, and F. Anstey, 1-29. New York: Longmans, Green \& Co.

Mooney, Shawn R. 1992. "Colliding Stars: Heterosexism in Biographical Representations of Somerville and Ross." The Canadian Journal of Irish Studies, 18.1: 157-75. DOI: http://dx.doi.org/ $10.2307 / 25512906$

Morrison, Kevin A., ed. 2019. Walter Besant: The Business of Literature and the Pleasures of Reform. Liverpool: Liverpool University Press.

Neetens, Wim. 1990. "Problems of a 'Democratic Text:' Walter Besant's Impossible Story.” Novel: A Forum on Fiction, 23.3: 247-64. DOI: https://doi.org/10.2307/1345952

Newton, Esther. 1989. “The Mythic Mannish Lesbian: Radclyffe Hall and the New Woman.” In Hidden from History: Reclaiming the Gay and Lesbian Past, edited by Martin Bauml Duberman, Martha Vicinus and George Chauncey, 281-93. New York: Penguin.

O'Connor, Maureen. 2010. The Female and the Species: The Animal in Irish Women's Writing. Oxford: Lang.

Reid, Michael. 2001. "The Aesthetics of Ascesis: Walter Besant and the Discipline of Form in The Golden Bowl." Henry James Review, 22.3: 278-85. DOI: https://doi.org/10.1353/hjr.2001.0031

Rose, Lucy Ella. 2018. Suffragist Artists in Partnerships: Gender, Word and Image. Edinburgh: Edinburgh University Press.

Shelley, Percy B. [1821] 1964. A Defence of Poetry. In Shelley. Selected Poems and Prose, edited by G. M. Matthews, 168-85. Oxford: Oxford University Press. 
Smith-Rosenberg, Carroll. 1985. Disorderly Conduct: Visions of Gender in Victorian America. New York: Oxford University Press.

Somerville, Edith E., and Martin Ross. 1889. An Irish Cousin. London: Richard Bentley and Son.

Somerville, Edith E., and Martin Ross. 1894. The Real Charlotte. 3 vols. London: Ward and Downey.

Somerville, Edith E., and Martin Ross. 1898. The Silver Fox. London: Lawrence and Bullen.

Somerville, Edith E., and Martin Ross. 1899. Some Experiences of an Irish R.M. London: Longmans, Green, \& Co.

Somerville, Edith E., and Martin Ross. 1908. Further Experiences of an Irish R.M. London: Longmans, Green, \& Co.

Somerville, Edith E., and Martin Ross. 1911. Dan Russell the Fox. London: Methuen.

Somerville, Edith E., and Martin Ross. 1915. In Mr. Knox's Country. London: Longmans, Green, \& Co.

Somerville, Edith E., and Martin Ross. 1917. Irish Memories. London: Longmans, Green, \& Co.

Somerville, Edith CE., and Martin Ross. 1946a. "Two of a Trade." Irish Writing, 1: 79-85.

Somerville, Edith E., and Martin Ross. 1946b. Happy Days. London: Longmans, Green \& Co.

Stillinger, Jack. 1991. Multiple Authorship and the Myth of the Solitary Genius. Oxford: Oxford University Press.

Stone, Marjorie, and Judith Thompson. 2006. "Contexts and Heterotexts: A Theoretical and Historical Introduction." In Literary Couples, Collaborators, and the Construction of Authorship, edited by Marjorie Stone and Judith Thompson, 3-37. Madison, WI: University of Wisconsin Press.

Storer, Richard. 2019. “'Another Like Me:’ The Literary Partnership of Walter Besant and James Rice.” In Walter Besant: The Business of Literature and the Pleasures of Reform, edited by Kevin A. Morrison, 39-54. Liverpool: Liverpool University Press.

Sturgeon, Mary. 1922. Michael Field. New York: Macmillan.

Swafford, Kevin. 2007. Class in Late-Victorian Britain: The Narrative Concern with Social Hierarchy and its Representation. Youngstown, NY: Cambria Press.

Swafford, Kevin. 2019. "The Ethics of Perception and the Politics of Recognition: Walter Besant's 'All Sorts and Conditions of Men." In Walter Besant: The Business of Literature and the Pleasures of Reform, edited by Kevin A. Morrison, 171-86. Liverpool: Liverpool University Press.

Thain, Marion. 2007. Michael Field. Poetry, Aestheticism, and the Fin de Siècle. Cambridge: Cambridge University Press.

Vicinus, Martha. 2004. Intimate Friends. Women Who Loved Women, 1778-1928. Chicago: University of Chicago Press.

Weekes, Anne O. 1990. Irish Women Writers: An Uncharted Tradition. Lexington: University Press of Kentucky.

Weiner, Deborah W. 1994. Architecture and Social Reform in Late-Victorian London. Manchester: Manchester University Press.

Wood, Elizabeth. 1994. "Ghost Shockers: A Parable of Lesbian Life." Australian Feminist Studies, 20 (Summer): 9-23. DOI: https://doi.org/10.1080/08164649.1994.9994740

York, Lorraine M. 2002. Rethinking Women's Collaborative Writing. Toronto: University of Toronto Press. 